\title{
Stimulus-onset asynchrony can aid odor segregation
}

\author{
Thomas Nowotny ${ }^{1 *}$, C Giovanni Galizia², Paul Szyszka² \\ From 1st International Workshop on Odor Spaces \\ Hannover, Germany. 4-7 September 2013
}

Insects have a remarkable ability to identify and track odor sources in multi-odor backgrounds. Recent behavioral experiments show that this ability relies on detecting millisecond stimulus asynchronies between odors that originate from different sources [1]. Honeybees are able to distinguish mixtures where both odors arrive at the same time (synchronous mixtures) from those where odor onsets are staggered (asynchronous mixtures) even if the delay is only a few milliseconds.

On this poster we explore asynchronous mixture recognition in a model of the honeybee antennal lobe. We demonstrate how local neuronal processing can translate the small onset time difference into lasting differences in the response pattern in the antennal lobe and hypothesize that a mechanism of this kind could facilitate odor-background segregation in downstream circuits of the olfactory pathway. We present a detailed data-driven model of the bee antennal lobe that reproduces a large data set of experimentally observed odor responses [2] and demonstrate with this model that our hypothesis is consistent with the current knowledge of the olfactory circuits in the bee brain.
doi:10.1186/2044-7248-3-S1-P12

Cite this article as: Nowotny et al: Stimulus-onset asynchrony can aid odor segregation. Flavour 2014 3(Suppl 1):P12.

\section{Authors' details}

${ }^{1}$ CCNR, School of Engineering and Informatics, University of Sussex, Brighton, BN1 9QJ, UK. ²Fachbereich Biologie, Universität Konstanz, 78457 Konstanz, Germany.

\section{Published: 16 April 2014}

\section{References}

1. Szyszka P, Stierle JS, Biergans S, Galizia CG: The Speed of Smell: OdorObject Segregation within Milliseconds. PLoS One 2012, 7:e36096.

2. Ditzen M: Odor concentration and identity coding in the antennal lobe of the honeybee Apis mellifera. Ph.D. thesis Freie Universität Berlin. Berlin; 2005 .

${ }^{1}$ CCNR, School of Engineering and Informatics, University of Sussex, Brighton, BN1 9QJ, UK

Full list of author information is available at the end of the article
Submit your next manuscript to BioMed Central and take full advantage of:

- Convenient online submission

- Thorough peer review

- No space constraints or color figure charges

- Immediate publication on acceptance

- Inclusion in PubMed, CAS, Scopus and Google Scholar

- Research which is freely available for redistribution 